\title{
Strategies And Initiatives That Revitalize Wesley College STEM Programs
}

\author{
Malcolm J. D’Souza, Ph.D., Wesley College, Dover, Delaware (DE), USA \\ William K. Kroen, Ph.D., Wesley College, Dover, Delaware (DE), USA \\ Charlene B. Stephens, M.A., Wesley College, Dover, Delaware (DE), USA \\ Richard J. Kashmar, Ph.D., Wesley College, Dover, Delaware (DE), USA
}

\begin{abstract}
Church-related small private liberal arts baccalaureate minority-serving institutions like Wesley College have modest endowments, are heavily tuition-dependent, and have large numbers of financially-challenged students. In order to sustain the level of academic excellence and to continue to build student demographic diversity in its accessible robust Science and Mathematics (STEM) programs, the faculty sought federal and state funds to implement a coordinated program of curriculum enhancements and student support programs that will increase the number of students choosing STEM majors, increase their academic success, and improve retention.
\end{abstract}

Keywords: Wesley College; STEM Education; Retention; Student Success; Minority Serving Institution (MSI); SAT; NIH NIGMS (IDeA) INBRE; NSF EPSCoR; NSF S-STEM; Cannon Scholar program; DE-INBRE; DEEPSCoR

\section{INTRODUCTION}

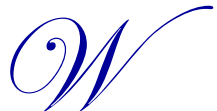
esley College (Wesley) is a small private coeducational baccalaureate institution designated by the federal government as a minority-serving institution (MSI) in Delaware (DE). This liberal arts college is fully accredited through the Middle States Commission on Higher Education. For the 2013-2014 academic year (AY), the Office of Institutional Research reported that its undergraduate student population of 1600 was comprised of 839 females (52\%) and 761 males (48\%). The AY 2013 breakdown of the College's demographics was 43\% Caucasian; 39\% African American; 5\% Hispanic; 3\% Biracial; 1\% Asian; 1\% Native- American or Pacific Islander; and $8 \%$ of the undergraduates classified themself as being of an unknown race. The 2013 freshman cohort was made up of 428 students.

In the areas of science, technology, engineering and mathematics (STEM), Wesley offers Bachelor of Science (B.S.) degrees in biology, biological chemistry, environmental science, environmental policy, mathematics, and medical technology. A Master's program (M.S.) is available in environmental science. In AY 2013-2014, there were 110 STEM majors studying in Cannon Hall, the science \& math building, named for alumna/ scientist Annie Jump Cannon.

Recent higher education peer-reviewed literature (Fortenberry, Didion, Cady, Jing, \& Raghavan, 2011; Gasman \& Nguyen, 2014; Habley, Bloom, Robbins, \& Robbins, 2012; Hu, McCormick, \& Gonyea, 2012; Jones, 2011; Luke \& Robert, 2015; Schreiner, Noel, \& Cantwell, 2011) suggests that ethnicity, gender, socioeconomic status, and student engagement are four crucial predictors of persistence behaviors for graduation rates at baccalaureate institutions. Additionally, for racial and ethnic minority students enrolled in the STEM areas of study, research has shown that high-school preparedness for college based on the scores achieved on the Scholastic Aptitude Test (SAT), first-year college science and mathematics course grades, college-debt, and attrition rates are important factors for student success (Ackerman, Kanfer, \& Beir, 2013; Anderson \& Kim, 2006; Bird, 2010; Chang, Sharkness, Hurtado, \& Newman, 2014; Chen \& Kelly, 2013; Cole \& Espinoza, 2008; Felder \& Brent, 2005; Fortenberry et al., 2011; Garriott, Flores, \& Martens, 2013; Gales \& Ampaw, 2014; House, 1995; Lewis, 2014; 
Perez, Cromley, \& Kaplan, 2014; Reid \& Moore, 2008; Stange, 2015; Tai, Sadler, \& Mintzes, 2006; Tinto, 2012; $\mathrm{Xu}, 2013)$.

\section{NEEDS ASSESSMENT AT WESLEY COLLEGE}

Wesley is committed to engaging all stakeholders to strengthen the institution's academic programs, institutional management, and fiscal stability to carry out its mission. A recent self-study illustrates this commitment. In AY 2011, Wesley, using a grant from the Jessie Ball duPont Foundation contracted with Credo (n. d.) higher-education consultants to conduct a year-long comprehensive analysis of our strengths, aspirations, and results regarding retention. A five-member Credo team came to campus for 3 days to conduct focus groups and interview more than 150 faculty, staff and students. Credo conducted an in-depth analysis of academic support services, student affairs, residence life, financial aid, student accounts, athletics, and other campus offices.

The study collected information from a variety of stakeholders through several different sources including: (a) admitted student research (a web-based survey sent to all admitted matriculating and non-matriculating students that focuses on why students make the choice they do and how matriculating students and non-matriculating students differ); (b) a "Why Students Stay" Analysis (a 34 question Likert-style survey that reveals the interplay between institutional, personal, and external factors that influence student persistence decisions); (c) and Retention $\mathrm{Ace}^{\circledR}$ (a predictive model used Fall 2008 on the first-time, full-time freshmen cohort to determine the likelihood of persisting to sophomore year).

Credo's comprehensive analysis showed that Wesley serves a significant number of students from populations that traditionally have not had access to higher educational opportunities. Of Wesley students, $98 \%$ receive merit scholarships and over 95\% receive some form of federal financial aid. Over half of all the undergraduate students are PELL eligible, with a median adjusted gross family income of $\$ 33,274$ and average adjusted gross income just under $\$ 24,000$. Parents Plus Loans were denied for $50 \%$ of this population.

In the Credo study, students identified the top three reasons for not returning as (a) lack of finances $(40 \%)$, (b) lack of academic ability (20\%), and (c) lack of academic preparation (16\%). The Credo report clearly proved that at Wesley, financial challenges are the most significant barrier to retention. Recommendations were also made for the utilization of proven high impact strategies to increase success, retention, and graduation rates (Beck \& Davidson, 2001; Burkum, Habley, McClanahan, \& Valiga, 2010; Cole \& Espinoza, 2008; Felder \& Brent, 2005; Fortenberry et al., 2011; Garriott et al., 2013; Habley \& McClanahan, 2010; Kuh, 2008; Stassen, 2003; Szelenyi, Denson, \& Inkelas, 2013; Tinto, 2012).

Table 1 shows that for 2010-2013 the College had an average first- to second-year retention rate (for firsttime, full-time, undergraduate students) of 46\%. In comparison, according to the 2010-2013 ACT Institutional Data Files, the average freshman to sophomore retention rates for peer institutions (i.e., those with an average SAT score range of $1230-1530$ ) was $56 \%$, placing Wesley well below the average. 
Table 1. First-time, Full-time, (FTFT) Undergraduate Retention Rates for All Wesley College Programs

\begin{tabular}{|c|c|c|c|c|c|c|c|}
\hline $\begin{array}{l}\text { Academic } \\
\text { Cohort }\end{array}$ & $\begin{array}{c}\text { Freshman } \\
1^{\text {st }} \text { Year }\end{array}$ & $\begin{array}{c}\text { Retained to } 2^{\text {nd }} \\
\text { year }\end{array}$ & $\begin{array}{c}\text { \% Retained to } \\
2^{\text {nd }} \text { year } \\
\end{array}$ & $\begin{array}{c}\text { Retained to } \\
3^{\text {rd }} \text { year }\end{array}$ & $\begin{array}{c}\text { \% Retained to } \\
3^{\text {rd }} \text { year } \\
\end{array}$ & $\begin{array}{c}\text { Retained to } \\
4^{\text {th }} \text { year }\end{array}$ & $\begin{array}{c}\% \text { Retained to } 4^{\text {th }} \\
\text { year }\end{array}$ \\
\hline $\begin{array}{l}2010 \text { FTFT } \\
\text { Freshmen }\end{array}$ & 488 & 193 & $39.5 \%$ & 121 & $\begin{array}{c}24.8 \% \text { (from } \\
1^{\text {st }} \text { year) } \\
62.7 \% \text { (from } \\
2^{\text {nd }} \text { year) } \\
\end{array}$ & 108 & $\begin{array}{c}22.1 \% \text { (from } 1^{\text {st }} \\
\text { year) } \\
89.3 \% \text { (from } \\
3^{\text {rd }} \text { year) } \\
\end{array}$ \\
\hline $\begin{array}{l}2011 \text { FTFT } \\
\text { Freshmen }\end{array}$ & 493 & 195 & $39.6 \%$ & 124 & $\begin{array}{c}25.2 \% \text { (from } \\
1^{\text {st }} \text { year) } \\
63.6 \% \text { (from } \\
2^{\text {nd }} \text { year) } \\
\end{array}$ & 112 & $\begin{array}{c}22.7 \% \text { (from } 1^{\text {st }} \\
\text { year) } \\
90.3 \% \text { (from } \\
3^{\text {rd }} \text { year) } \\
\end{array}$ \\
\hline $\begin{array}{l}2012 \text { FTFT } \\
\text { Freshmen }\end{array}$ & 536 & 281 & $52.4 \%$ & 225 & $\begin{array}{c}42.0 \% \text { (from } \\
1^{\text {st }} \text { year) } \\
80.1 \% \text { (from } \\
2^{\text {nd }} \text { year) } \\
\end{array}$ & $\begin{array}{c}\text { Not } \\
\text { Available }\end{array}$ & $\begin{array}{c}\text { Not } \\
\text { Available }\end{array}$ \\
\hline $\begin{array}{l}2013 \text { FTFT } \\
\text { Freshmen }\end{array}$ & 428 & 221 & $51.6 \%$ & $\begin{array}{c}\text { Not } \\
\text { Available }\end{array}$ & $\begin{array}{c}\text { Not } \\
\text { Available } \\
\end{array}$ & $\begin{array}{c}\text { Not } \\
\text { Available }\end{array}$ & $\begin{array}{c}\text { Not } \\
\text { Available }\end{array}$ \\
\hline $\begin{array}{l}\text { Average } \\
\text { Retention From } \\
\text { First Year } \\
\end{array}$ & & & $46 \%$ & & $31 \%$ & & $22 \%$ \\
\hline
\end{tabular}

Disaggregating annual retention rates by undeclared status, race, and gender, the College observed that $59 \%$ or less of students in any high-risk category returned 1 year later. Undeclared students fared the worst with only a $23 \%$ four year average retention rate ("Institutional Research," 2011) followed by Black males (36\%), White males (47\%), Black females (51\%), and White females (51\%). Over $40 \%$ of the incoming classes were comprised of first-generation college students. First-generation college students have lower academic persistence rates and degree attainment rates than their peers with parents who have college degrees (Garriott et al., 2013).

Overall graduation rates at Wesley College are also low. For the previous 3 years (2010-2013), the 6-year graduation rate (i.e., bachelor's degree obtained within 6 years) averaged 32\%. The low retention and graduation statistics can be attributed in part to the fact that Wesley College serves a significant number of students from populations that traditionally have not had access to higher educational opportunities. These students are very likely to enter college unprepared. The Wesley first-time, full-time freshmen had an average high school GPA of 2.7 and an average composite SAT score of 1265, which is at the very low end of the ACT Institutional Data comparison SAT profile (ACT, 2010-2013). The 1265 SAT score also puts them at the 23rd percentile of all college-bound seniors, meaning Wesley students, on average, did better than only $23 \%$ of students taking the exam. As a result of the low SAT scores, many students were admitted conditionally and needed to take developmental mathematics and English courses to address academic deficiencies before moving into college- level courses. In AY 2013-2014, 53\% of Wesley freshmen took developmental English, developmental math, or both.

\section{ANALYSIS OF THE STEM PROGRAM NEEDS}

In the STEM fields, Wesley offers baccalaureate degrees that align with national standards in biology, biological chemistry, environmental science, environmental policy, math, and medical technology. In biology, biological chemistry, medical technology, and environmental science, the coursework in the first two years has considerable overlap in the core science and math requirements. Instrumentation, analytical techniques, critical analysis of scientific data, informatics, writing, and communication skills are strongly emphasized in the science and math curriculum (D'Souza \& Wang, 2012). Students majoring in medical technology complete a clinical experience in their senior year and students in the other science and math programs have a year-long senior capstone researchthesis requirement.

Table 2 provides the Wesley retention data for first-time, full-time STEM undergraduates. Across four freshman STEM cohorts (2010-2014), the average (STEM-to-STEM) retention rate is $44 \%$ which was close to the overall College FTFT retention rate $(46 \%)$. 
Table 2. FTFT Retention Rates for the Wesley College STEM Programs 2010-2014

\begin{tabular}{ccccccc}
\hline $\begin{array}{c}\text { Academic } \\
\text { Year }\end{array}$ & $\begin{array}{c}\text { \# Freshmen } \\
\text { entered }\end{array}$ & $\begin{array}{c}\text { \# Retained in \# Retained at Wesley } \\
\text { major }\end{array}$ & $\begin{array}{c}\text { \# Dropped out } \\
\text { in other major }\end{array}$ & $\begin{array}{c}\text { \% Retained in } \\
\text { of Wesley }\end{array}$ & $\begin{array}{c}\text { \% Retained at Wesley } \\
\text { STEM Majors }\end{array}$ & \begin{tabular}{c} 
(in any Major) \\
\hline $2010-2011$
\end{tabular} \\
32 & 12 & 2 & 18 & $37.5 \%$ & $43.8 \%$ \\
$2011-2012$ & 32 & 13 & 5 & 13 & $40.6 \%$ & $56.3 \%$ \\
$2012-2013$ & 28 & 13 & 2 & 9 & $46.4 \%$ & $53.6 \%$ \\
$2013-2014$ & 25 & 13 & 3 & $52.0 \%$ & $64.0 \%$ \\
\hline
\end{tabular}

At Delaware's flagship research institution, the University of Delaware (UD), the average SAT score for the entering STEM freshman class was 1800 and the STEM-to-STEM retention rate across five entering cohorts (2007-2011) was shown to be 79\% (Chen \& Kelly, 2013). In comparison, the institution-wide 2007-2011 FTFT retention rate averaged $92 \%$. The 4-year graduation rates for the 2007 and 2008 STEM-to-STEM cohorts were $47 \%$ and $52 \%$ respectively. The study further showed that female, Delawareans, first-generation, under-represented minorities, and Pell Grant recipients were more likely to switch to non-STEM majors as opposed to persisting in STEM fields. Additionally, those majoring in Biological Sciences (all biology-related disciplines and agricultural science) were shown to have the highest dropout rate (Chen \& Kelly, 2013).

Incoming Wesley STEM majors had average SAT scores that were in the bottom quarter of the national incoming freshman class. Furthermore for the cohort year 2007, the STEM programs had a 6-year graduation rate of $27 \%$ (the College 6-year graduation rate for 2007 was $22 \%$ ). Hence, the much higher attrition rates observed in the Wesley STEM programs when compared to those seen at UD, builds on long- established observations that most students perform in the range that their entering credentials suggest (Bird, 2010; Chen \& Kelly, 2013; Felder \& Brent, 2005; Garriott et al., 2013; House, 1995; Jones, 2011; Lewis, 2014; Reid \& Moore, 2008, Tai et al., 2006).

To probe further factors associated with Wesley's STEM attrition rate, the STEM faculty consequently evaluated the success rates of students in the typical first-year general biology and general chemistry courses (Biology I and Chemistry I). The anticipated sequence of courses for a typical Wesley science student in biological chemistry, biology, environmental science, and medical technology would be to complete College Writing, math at the level of Pre-Calculus I (or higher), Chemistry I, The Scientific Process, and a First Year Seminar (FYS) during the first semester. In the second semester, Wesley science majors complete College Writing II (Literature for Composition), sequential math, Organic Chemistry I, and Biology I.

The Scientific Process is a 1-hour-per-week course that stresses critical reading, college success assignments (such as summarizing articles and time management), and has students design and complete a small research project using Wisconsin Fast Plants. Students begin the year-long organic chemistry sequence during the second semester of their freshman year to allow for additional time for some students (D'Souza \& Wang, 2012) to catch up on their math (Pre-Calculus) requirement that was shown to be imperative (Bird, 2010; House, 1995; Lewis, 2014; Tai et al., 2006) in achieving success in general chemistry. The science department also consciously moved Biology I to the second semester due to the realization that incoming freshmen needed to show additional success metrics in basic college general education course concepts (especially in writing) prior to taking Biology I. This was done to allow this group of students the continuing opportunity to develop the ability to synthesize information obtained in general biology.

The STEM faculty realized that the logical reasoning skills for many of the incoming Wesley freshmen are very inadequate and likely limit many students from being able to synthesize the information required in biology and chemistry. Therefore in this paper (and for a poster presentation at the 2015 American Association for the Advancement of Science National Meeting; D’Souza, Kroen, \& Kashmar, 2015) we first explored possible correlations between success in a specific level of college mathematics and the successful completion of Biology I, as this course had no math prerequisite. A second study involved an analysis of correlations observed between final grades in Chemistry I (typically completed in the first semester of the freshman year) versus grades obtained in in Biology I (taken in the second semester of the freshman year). A recent paper (Allen, 2014) also raised the possibility that critical reading is a deficient area for some students who struggle to comprehend biology. This observation complements the very low average SAT score of the incoming Wesley freshman cohort. Hence, the successful completion (in terms of final grades achieved) of college writing prior to Biology I was evaluated next. 
Initially, from instructor course records obtained for the 2010 through 2014 spring semesters, a spreadsheet was compiled of all students who enrolled in Biology I (over the 5 academic years). While the majority of these students expressed an interest in pursuing STEM majors (or a minor in biology), some were clearly majoring in nonSTEM fields. However, all students $(\mathrm{n}=241)$ were included in this analysis, including those who may have repeated Biology I. Final grades in any math and English courses taken in the semester prior to enrolling in Biology I, or in the math and English courses concurrently completed with Biology I were obtained from the Registrar's Office. Letter grades were converted to a four-point scale ("A" = 4, "B" = 3, etc.) prior to computing Microsoft Excel ${ }^{\circledR}$ based statistical and regression analyses. Students were deemed to have successfully completed a course only if they received a grade of "C" or higher as a final grade in that course, while grades of "D", "F", or "W" were considered to be failing. One student completed a non-sequential math course (Foundations of Geometry) and was excluded from all computations (see Table 3).

In Table 3, each row shows the Wesley math course a student took the semester before enrolling in Biology I, the student outcomes in that math course, the final student grade in Biology I, the total number of students in that category, and the success of that category in Biology I (Total $n=240)$.

Table 3. Biology I Success Based Upon Math Progression at Wesley College

\begin{tabular}{|c|c|c|c|c|c|c|}
\hline \multirow{2}{*}{ Previous math course } & \multirow{2}{*}{$\begin{array}{c}\text { Passed } / \\
\text { failed }\end{array}$} & \multicolumn{3}{|c|}{ Grade earned in Biology I } & \multirow{2}{*}{$\begin{array}{l}\text { Number of } \\
\text { students }\end{array}$} & \multirow{2}{*}{$\begin{array}{l}\text { Biology I } \\
\text { success rate }\end{array}$} \\
\hline & & A or B & $\mathbf{C}$ & $\mathbf{D}, \mathbf{F}, \mathbf{W}$ & & \\
\hline \multirow{2}{*}{$\begin{array}{l}\text { Basic Math Skills } \\
\text { (remedial) }\end{array}$} & fail & 0 & 0 & 4 & 4 & 0 \\
\hline & pass & 0 & 1 & 17 & 18 & $6 \%$ \\
\hline \multirow[t]{2}{*}{ Fundamentals of Algebra } & fail & 0 & 0 & 7 & 7 & 0 \\
\hline & pass & 2 & 3 & 23 & 28 & $18 \%$ \\
\hline \multirow[t]{2}{*}{ Intermediate Algebra } & fail & 0 & 2 & 11 & 13 & $15 \%$ \\
\hline & pass & 2 & 12 & 27 & 41 & $34 \%$ \\
\hline \multirow{2}{*}{$\begin{array}{l}\text { Math Concepts II } \\
\text { (general core course) }\end{array}$} & fail & 0 & 0 & 4 & 4 & 0 \\
\hline & pass & 0 & 5 & 7 & 12 & $42 \%$ \\
\hline \multirow[t]{2}{*}{ Pre-Calculus I } & fail & 0 & 2 & 10 & 12 & $17 \%$ \\
\hline & pass & 9 & 16 & 11 & 36 & $69 \%$ \\
\hline \multirow[t]{2}{*}{ Pre-Calculus II } & fail & 0 & 0 & 1 & 1 & 0 \\
\hline & pass & 0 & 4 & 0 & 4 & $100 \%$ \\
\hline \multirow{2}{*}{ Intro Statistical Methods } & fail & 0 & 0 & 1 & 1 & 0 \\
\hline & pass & 5 & 7 & 3 & 15 & $80 \%$ \\
\hline \multirow[t]{2}{*}{ Calculus I } & fail & 2 & 2 & 1 & 5 & $80 \%$ \\
\hline & pass & 7 & 6 & 1 & 14 & $93 \%$ \\
\hline No recorded Math course & & 5 & 6 & 14 & 25 & $44 \%$ \\
\hline
\end{tabular}

The overall pass rate for Biology I for these five cohorts was $41 \%$. Successful completion of a college-level math course during the previous semester greatly increased the Biology I pass -rate (Table 3). For all students taking pre-college math courses (i.e., algebra or below) in the previous semester, the biology success rate was only $20 \%$; $46 \%$ of students in Biology I fell into this category. Over two-thirds $(68 \%)$ of students who took Pre-Calculus I or higher in the prior semester succeeded at Biology I. Additionally, no student who took a math course below PreCalculus I earned an "A" grade in Biology I. Not surprisingly, failing any math course in the prior semester increases the likelihood of subsequently failing Biology I.

In Table 4, from the 2009-2013 course records, the final student grades of students in Chemistry I (taken in the first semester of the freshman year) were first documented. These student records were then (manually) compared to subsequent individual performance in Biology I.

Of students taking Biology I, 37\% had previously taken and successfully completed Chemistry I in the previous semester. Their success rate was $55 \%$, and they earned a higher percentage of $\mathrm{A}, \mathrm{B}$, and $\mathrm{C}$ grades when compared to students who had not previously taken chemistry. For students who had both majors courses, there was a mild correlation between their final grade in Chemistry I and Biology I (Figure $1 ; R^{2}=0.5036$, see Figure 1). 
Table 4. Wesley Student Performance in Biology I

Comparing Completers of Chemistry I with Noncompleters of Chemistry I (2009 to 2013)

\begin{tabular}{|c|c|c|c|c|}
\hline & \multicolumn{2}{|c|}{$\begin{array}{l}\text { Biology I Grades of Students with no prior } \\
\text { Chemistry I (135 students) }\end{array}$} & \multicolumn{2}{|c|}{$\begin{array}{c}\text { Biology I Grades of Students that had Chemistry } \\
\text { I first (80 students) }\end{array}$} \\
\hline & No. Students & Percent & No. Students & Percent \\
\hline A's & 3 & 2.2 & 8 & 10.0 \\
\hline B's & 9 & 6.7 & 14 & 17.5 \\
\hline C's & 27 & 20.0 & 22 & 27.5 \\
\hline D's & 17 & 12.6 & 20 & 25.0 \\
\hline F's & 30 & 22.2 & 9 & 11.2 \\
\hline W's & 49 & 36.6 & 7 & 8.7 \\
\hline
\end{tabular}

Figure 1. Wesley College Biology I Final Grade Average versus Chemistry I Final Grade Average, 2009-2013

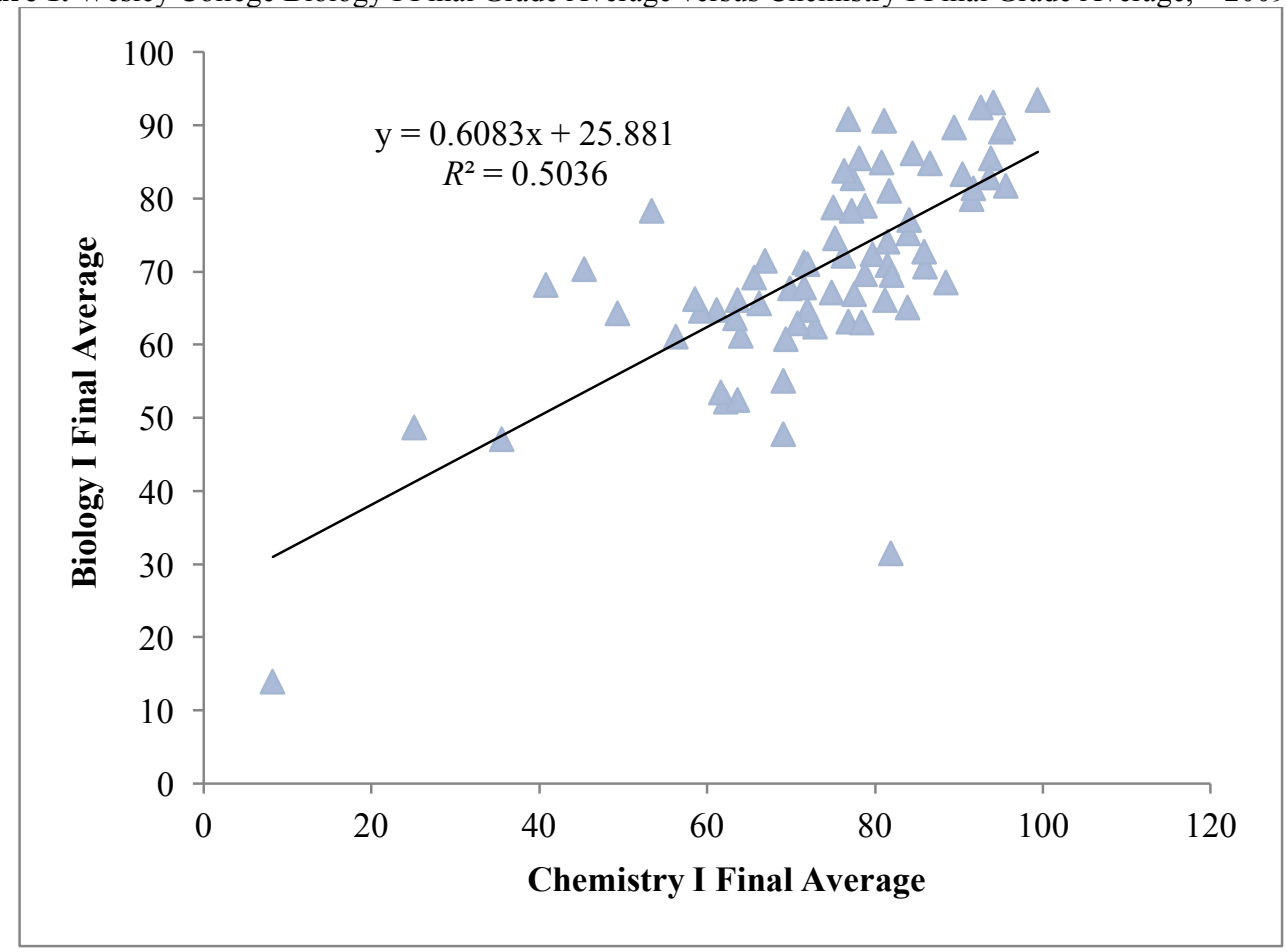

At Wesley, most students who are denied enrollment in Chemistry I have an insufficient math background. The success rate in Biology I for students with no prior chemistry was just $29 \%$. Hence, results from this study do suggest that structured analytical comprehension strategies that usually begin to develop in mathematics coursework (Bird, 2010; Chang et al., 2014; Chen \& Kelly, 2013; Garriott et al., 2013; Lewis, 2014; House, 1995; Tai et al., 2006) are very essential for the successful completion of all general science courses. In AY 2014, the Wesley science department instituted a prerequisite that students must successfully complete Intermediate Algebra (at the minimum) prior to taking either Chemistry I or Biology I. This policy was instituted to avoid needlessly setting up a student for failure in any first-year science course and thus avoiding the probability of creating some loss of interest in science.

There was a less clear-cut relationship between final grades obtained in a previous writing course and subsequent final grades in Biology I, mainly because $96 \%$ of the surveyed students passed College Writing with a grade of "C" or higher and 95\% passed Literature for Composition, (which most students take concurrently with Biology I). Not surprisingly, students who enrolled in Basic Writing and the few students who did fail their English course also failed Biology I. Very mild support is shown for Allen's (2014) findings of a strong correlation between reading ability and science assessment score, as this study examined student course grades, a more "blunt 
instrument" for evaluation than the measures to which Allen had access. The relationship between success in science courses and an entering student's SAT- $R$ (Reading) score might be a more meaningful (and interesting) assessment.

\section{IMPLEMENTATION OF HIGH-IMPACT STRATEGIES TO IMPROVE OUTCOMES}

Wesley has documented significant successes with its better-prepared students. The Wesley STEM program is very committed to effective institution- wide practices (Anderson \& Kim, 2006; Fortenberry et al., 2011; Kuh, 2008; Tai et al., 2006; Tinto, 2012; Xu, 2013) to balance the academic experience, social integration, campus involvement and career awareness that help to support and retain diverse students. Since AY 2002 (Table 5), with support from an Institutional Development Award (IDeA) from the National Institute of General Medical Sciences (NIGMS) at the National Institutes of Health (DE-INBRE program) and a National Science Foundation (NSF) Experimental Program to Stimulate Competitive Research grant (DE-EPSCoR program), the faculty implemented a STEM Directed Research program. This DE-INBRE- and DE-EPSCoR- sponsored undergraduate research program has had a retention rate of $94 \%$, a graduation rate of $100 \%$, and significant numbers of its participants have gained entry with competitive scholarships into graduate or professional programs (D'Souza, Dwyer, Allison, Miller, \& Drohan, 2011; D'Souza and Wang 2012). Additionally (as of March 2015), 57 undergraduate participants are coauthors on peer-reviewed publications and 74 have earned national or regional merit awards. The October 2012 issue of the European journal International Innovations highlighted the Wesley-STEM Directed Research Program as an example of "Transitioning Undergraduate Research in Science to Meet the Challenges of the 21st Century" (D’Souza, 2012).

Table 5. DE-INBRE/DE-EPSCoR Participant Outcomes 6- Months After Graduation

\begin{tabular}{lcc}
\hline \multicolumn{1}{c}{ Participant Outcome } & Number of Students & Percent of Students \\
\hline Seniors who participated in Directed Research 2002-2014 & 78 & $100 \%$ \\
Admitted to Ph. D. programs & 9 & $12 \%$ \\
Admitted to medical, PA, or advanced medical technology schools & 8 & $10 \%$ \\
Admitted to Master's Programs & 22 & $28 \%$ \\
Directly employed in STEM fields on graduation & 21 & $27 \%$ \\
Registered Nurses & 5 & $6 \%$ \\
Transferred to professional programs prior to graduation & 7 & $9 \%$ \\
Lost-contact & 6 & $8 \%$ \\
\hline
\end{tabular}

In 2005, Wesley faculty created the Wesley College Honors Program, which is explicitly designed for students with high academic ability and aspirations: entering students need a HS GPA of 3.3 and continuing Wesley students must maintain a GPA of 3.0. Students in this program are eligible to reside at the Joseph S. Bellmeyer Honors House or in Honors-designated wings within a specified residence hall. The Honors Program is based on the concept of a 'living-learning community' (Stassen, 2003; Szelényi et al., 2013) and had a total Fall-to-Fall retention rate (2005-2012 cohorts) of $84 \%$, far exceeding the overall College average of $46 \%$ (see Table 1 ).

In AY 2014, the Wesley College faculty developed a progressive core-curriculum model and implemented a signature undergraduate research experience piece embedded within this new core. This core dramatically altered the culture of the institution and championed our STEM efforts. Research has confirmed that undergraduate research is a "high impact practice" that supports increased retention and student success (Felder \& Brent, 2005; Fortenberry et al., 2011; Habley et al., 2012; Kuh, 2008; Tai et al., 2006; Tinto, 2012). Additionally, through sponsorship of the DE-INBRE and DE-EPSCoR programs, the College conducted several Faculty workshops to encourage participants in active pursuit of undergraduate research as standard teaching practice in their fields, in all First-Year Seminar (FYS) courses, and in all Frontiers in Science (SC) project-based STEM courses. The STEM-based FYS and SC courses are designed around a topic of the faculty member's choice and passion, but have a "science-related" theme to include an introduction to research/inquiry exercise in the form of team-based projects. For example, after a STEM- directed research project found that $30 \%$ of the Wesley undergraduate population was classified as being overweight and 20\% was classified as obese (D'Souza et al., 2015), an SC course on Diabetes was developed (for AY 2015) to provide students an opportunity to become more familiar with diabetes as it becomes more prevalent locally and nationally. In May 2014, International Innovations featured the Wesley STEM initiatives (D'Souza, Curran, \& Stotts) of integrating project-based learning into the liberal arts core- curriculum. 
This vibrant core curriculum revision helps all Wesley students, but particularly those from populations with lower retention rates, to engage earlier in their academic experience, and to follow a developmentally appropriate and systematic curriculum that integrates thinking across disciplines and begins engagement in undergraduate research.

Additionally, to encourage greater participation in undergraduate research across campus, the College also hosts an annual Scholars Day event, which is an opportunity for students to present their research completed under the mentoring of a faculty advisor. Specifically, it is designed to demonstrate, highlight, promote, and encourage scholarship. Students can present their results to the campus community through an oral presentation, a poster presentation, or a performance.

Through receipt of an NSF Scholarships in STEM (S-STEM) award (NSF DUE 1355554), the STEM faculty established the Cannon Scholar program that is designed to recruit and retain diverse, academically-talented STEM students (Cannon Scholars) who can thrive in our robust STEM programs in spite of unmet financial challenges. The main goal of the Cannon Scholars program is to increase qualifications of entering students, so the program anticipates that more students would enter Wesley College with higher math SAT scores and have the ability to take, and be successful in, STEM major courses earlier in their career. These better-prepared students would be more likely to persist as STEM majors.

To achieve our objectives, the College has implemented four major initiatives: (a) increased academic support for STEM freshmen and the recruitment of undeclared students to STEM majors by implementing a comprehensive first-year program (including first year seminars, common intellectual experiences, learning communities, student activities, and undergraduate research experiences), (b) strengthened academic programs (including course revisions) to improve student outcomes, (c) strengthened support structures for at-risk students (including early alert systems, extensive peer and faculty mentoring, and career guidance), and (d) financial scholarships for STEM students to address the financial resource issue.

To improve retention and with partial support from the DE-EPSCoR and DE-INBRE programs, the Office of Academic Affairs reorganized student support services to include an Executive- Director of Student Success and Retention (DSSR). The DSSR is integrating services (see Figure 2) for high need students, including a coordinated first-year program that consists of a series of orientation activities, programs, and courses to help students navigate the demands and challenges of college life, and forge connections with counselors, faculty, staff, and peers.

In recognition of the fact that many of our students are the first in their families to attend college, we have enhanced our support structures to improve coordination of mentoring these students. Wesley has implemented software for early alert and case management, Pharos $360^{\mathrm{TM}}$, enabling faculty and staff to record their interactions and communications concerning our students. In this case management software, the DSSR creates Care Areas for groups of students, such as STEM or Cannon Scholars, assigns Case Managers and closely monitors and mentors each of these students. This new system improves administrative efficiency and greatly aids in developing an infrastructure to identify, manage case notes, and mentor students.

The enhanced tutoring services also reflect the needs of Wesley students. The College hires high-achieving students (upper-class Cannon Scholars) recommended by faculty and trains them to standards set by the College Reading and Learning Association (CRLA). The Pharos $360^{\mathrm{TM}}$ software is used to record Session Reports each time a student visits a subject tutor and professors receive copies of each report. 
Figure 2. Wesley College Restructured Organizational Chart Academic Year 2014-2015

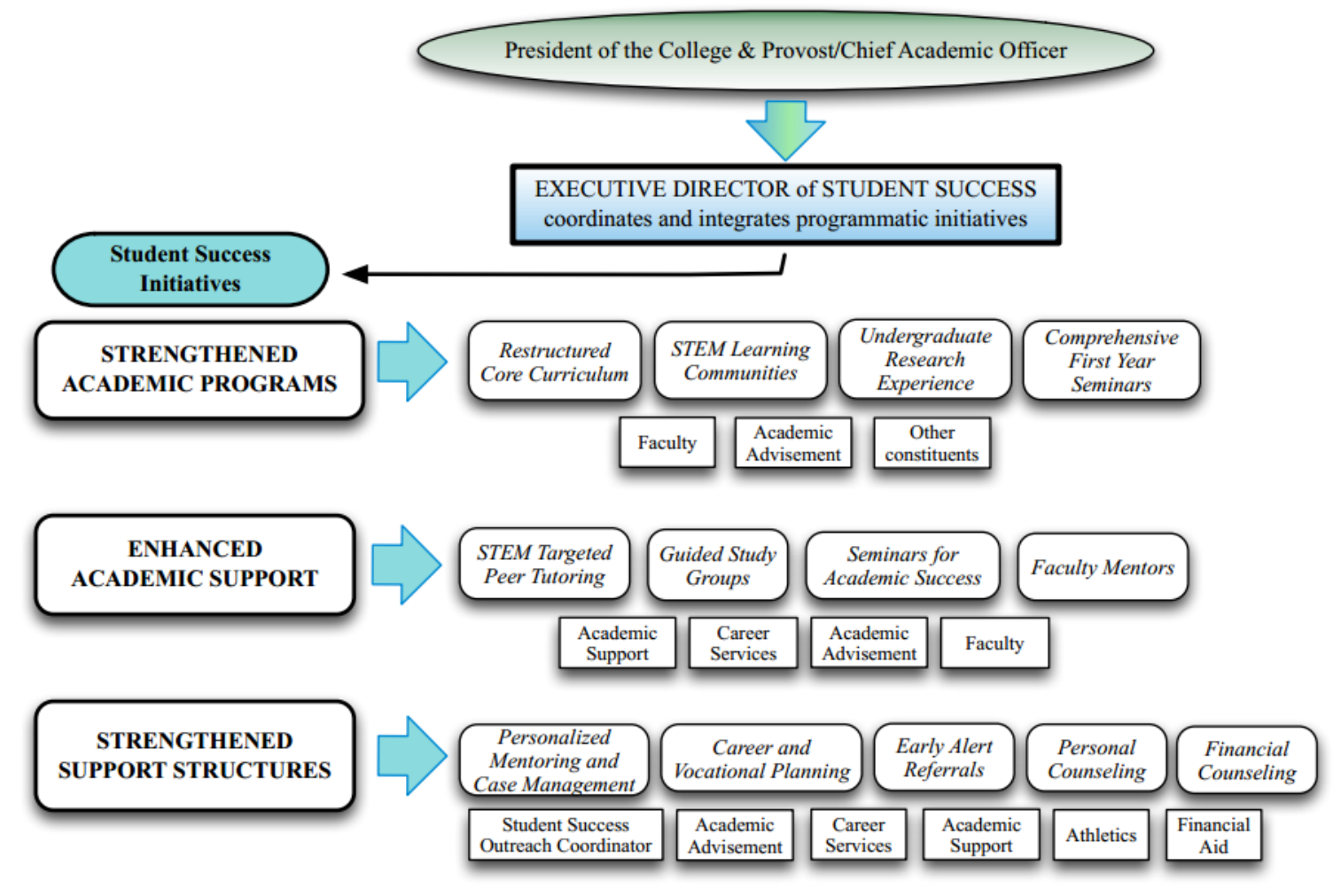

To recognize that some students will need assistance in areas that more experienced scholars take for granted, we have created our Seminars for Academic Success, a year-long series of workshops addressing strategies for successful students. These include the typical study skills such as note-taking, academic research, and test preparation, but also extend to use of technology and college etiquette.

The Career Development Center offers targeted seminars for resumes for the sciences, networking and interview skills. Students can complete online self-assessments on the Focus2Career ${ }^{\mathrm{TM}}$ software to fine-tune their career goals and trajectory. This early stage career initiative will help students develop academic and career goals and increase persistence rates (Kuh, 2008; Tinto, 2012).

\section{CONCLUSIONS}

The 2011 College-wide self-study strongly indicated that student finances and lack of college-level preparedness were having a significant detrimental effect on student retention at Wesley College. The observations of very low incoming freshman SAT scores coupled with resultant analyses of correlations observed between the final course grades in the first-year math, chemistry and biology courses, indicate that logical critical and creative thinking skills could be developed in wisely placed consequential STEM courses. This systematically-paced format should effectively prepare the students to catch up in the STEM track after inadequate high school preparation.

Federal and state infrastructure grants (NIH-NIGMS-INBRE, NSF-EPSCoR, NSF ARRA, and NSF SSTEM programs) facilitate and support the educational infrastructure of the College, increase diverse participation in the STEM fields, make the Wesley-STEM programs competitive, and greatly impacts student STEM-interests and careers. Additionally, these grants have allowed us to create multi-tiered mentoring strategies and curriculum reform 
that will have a lasting influence on student-centered learning that is guaranteed to become part of the academic culture at Wesley.

\section{ACKNOWLEDGEMENTS}

The authors acknowledge support from an Institutional Development Award (IDeA) from the National Institute of General Medical Sciences (NIGMS) at the National Institutes of Health (NIH grant no. P20GM103446, Delaware INBRE program); a National Science Foundation (NSF) Experimental Program to Stimulate Competitive Research grant IIA-1301765 (Delaware EPSCoR program); an NSF American Recovery and Reinvestment Act (ARRA) grant (NSF ARI R2 0960503); an NSF S-STEM grant (NSF DUE 1355554 - the Wesley College Cannon Scholar program); and the State of Delaware (Delaware Economic Development Office). The DE-INBRE and DE-EPSCoR grants were obtained through the leadership of the University of Delaware and the authors sincerely appreciate their efforts. The authors also acknowledge Ms. Jessica Hansen, Wesley College Office of Institutional Research, for her work in providing some of the data reported in this paper and Ms. Jessica Pilewski, Wesley College Coordinator of Tutoring Services, for her work in editing this paper.

\section{AUTHOR INFORMATION}

Malcolm J. D'Souza is Professor of Chemistry at Wesley College, in Dover, Delaware. He is the Principal Investigator on the Wesley College DE-INBRE, DE-EPSCoR, NSF ARRA, and Cannon Scholar (NSF S-STEM) programs. In 2009, to mark the occasion of its 50th anniversary, the College of Liberal Arts and Sciences, Northern Illinois University (NIU), recognized the accomplishments of Dr. D'Souza as one of its 50 most distinguished alumni of the college. In 2012, he was awarded the American Chemical Society's (ACS) E. Emmett Reid Award, which recognizes high-quality teaching in chemistry at small colleges in the ACS Mid-Atlantic region. In addition to his research in physical organic chemistry, he also has projects, presentations, and publications in the area of chemometrics, STEM education, weight-loss studies, and in the design of commercial databases that assist in the development of new pharmaceutical and agricultural products. Dr. D'Souza also serves as the Associate Dean of Interdisciplinary/Collaborative Sponsored Research. E-mail: malcolm.dsouza@wesley.edu (Corresponding author).

William K. Kroen is Professor of Biology at Wesley College. A graduate of Pennsylvania State University, he earned the Ph.D. at Duke University. His primary teaching duties at Wesley are Biology I and II, plus The Scientific Process. As an offshoot of developing the Scientific Process course, his examination of the backgrounds and successes of entering Wesley STEM students led to some of the curriculum changes in the majors mentioned here (including course sequence rearrangements). He served as chairperson of the Four-Year College and University Section of the National Association of Biology Teachers in 2010. E-Mail: william.kroen@wesley.edu.

Charlene B. Stephens is Executive-Director of Student Success and Retention at Wesley College and a graduate of Houghton College (NY) with a Masters of Arts in Writing and Journalism from Kent State University (OH). In addition to extensive teaching experience in English and Writing, she has many years of background in academic support and mentoring on the college level. She has worked as a Director of Academic Support, Director of Tutoring and Writing Centers and academic support faculty on the university level. She has written and presented national webinars on early alert processes. She is currently the Project Evaluator for the Cannon Scholar program at Wesley College. Email: charlene.stephens@wesley.edu.

Richard J. Kashmar is Professor of Chemistry and Physics at Wesley College. A graduate of Carnegie Mellon University, he received a Ph.D. in Physical Chemistry from the University of Pittsburgh. Dr. Kashmar's teaching responsibilities include the Chemistry I and II courses, as well as Physical Chemistry for Life Sciences and Analytical Chemistry. He has done research work involving the statistical comparison of student performance in the traditional freshman-sophomore chemistry sequence vs. the nontraditional sequence used at Wesley. He has presented his results at an American Chemical Society (ACS) National Meeting in 2009, at the Middle Atlantic Regional ACS Meeting in 2011, and at the 22nd Biennial Conference on Chemical Education in 2012 (where he also organized and moderated a symposium on nontraditional chemistry sequences).

E-mail: richard.kashmar@wesley.edu. 


\section{REFERENCES}

Ackerman, P. L., Kanfer, R., \& Beier, M. E. (2013). Trait complex, cognitive ability, and domain knowledge predictors of baccalaureate success, STEM persistence, and gender differences. Journal of Educational Psychology, 105(3), 911-927.

ACT. (2010-2013). ACT national collegiate retention and persistence to degree rates. Retrieved from Ruffalo Noel Levitz: Higher Education Consultants: https://www.noellevitz.com/papers-research-highereducation/student-retention-white-papers-and-trend-reports/act-collegiate-retention-persistence-rates

Allen, D. A. (2014). A test of the relationship between reading ability and standardized biology assessment scores. The American Biology Teacher, 76(4), 247-251.

Anderson, E. L., and Kim, D. (2006). Increasing the success of minority students in science and technology (No. 4). Washington, DC: American Council on Education.

Beck, H.P., and Davidson, W. B. (2001). Establishing an early warning system: Predicting low grades in college students from survey of academic orientations scores. Journal of Research in Higher Education, 42, 709723.

Bird, L. (2010). Logistical reasoning ability and student performance in general chemistry. Journal of Chemical Education, 87(5), 541-546.

Burkum, K., Habley, W., McClanahan, R., and Valigga, M. (2010). Retention: Diverse institutions $=$ diverse retention practices? (ACT Policy Report). Chicago, IL: ACT, Inc.

Chang, M. J., Sharkness, J., Hurtado, S., and Newman, C. B. (2014). What matters in college for retaining aspiring scientists and engineers from underrepresented racial groups. Journal of Research in Science Teaching, 51(5), 555-580.

Chen, D., and Kelly, H. (2013, November). Understanding the leaky STEM pipeline by taking a close look at factors influencing retention and graduation rates. Paper presented at the North East Association for Institutional Research $40^{\text {th }}$ Annual Conference, Newport, RI. Retrieved from https://www.udel.edu/IR/LeakySTEMPipeline.pdf

Cole, D., and Espinoza, A. (2008). Examining the academic success of Latino students in science technology engineering and mathematics (STEM) majors. Journal of College Student Development, 49(4), 285-300.

Credo. (n. d.). What we do. Whitsett, NC: Author. Retrieved from http://www.credohighered.com/about/what-we-do Delaware INBRE. (2014). Retrieved from www.inbre.udel.edu

D'Souza, Malcolm. (2012, October). Helping underrepresented STEM undergraduates. International Innovations. 87-88. Retrieved from http://www.wesley.edu/fileadmin/editors_images/Academics/Biology/p8688_Malcom_DSouza.pdf

D'Souza, M., Currran, K., Stotts, S. (2014, May). Tomorrow's Researchers. International Innovations. 98-101. Retrieved from http://www.wesley.edu/fileadmin/editors_images/Academics/Grants/INBRE/Malcolm_D_Souza_Intl_Inno vation_135_Research_Media.pdf

D’Souza, M. J., Dwyer, P., Allison, B. E., Miller J. M., and Drohan, J. (2011). Wesley College ignites potential with undergraduate student research program. Council of Undergraduate Research Quarterly, 32(2), 41-45.

D’Souza, M. J., Kroen, W. K., Kashmar, R. J. (2015, February). Strategies and initiatives to revitalize the undergraduate STEM programs at Wesley College. Paper presented at the American Association for the Advancement of Science 2015 Annual Meeting, San Jose, CA. Abstract retrieved from https://aaas.confex.com/aaas/2015/webprogram/Paper15500.html

D'Souza, M. J., Walls, K. J. E., Rojas, C., Everett, L. M., Wentzien, D. E. (in press 2015). Effect of gender and lifestyle behaviors on BMI trends in a sample of the first state's undergraduate population. American Journal of Health Sciences.

D’Souza, M. J., and Wang, Q. (2012). Inter-Institutional partnerships propel a successful collaborative undergraduate degree program in chemistry. Journal of College Teaching and Learning, 9(4), 245-252.

EPSCoR/IDeA Foundation. (2015). Retrieved from http://www.epscorideafoundation.org

Felder, R. M., and Brent, R. (2005). Understanding student differences. Journal of Engineering Education, 94 (1), $57-72$.

Fortenberry, N. L., Didion, C. J., Cady, B. T., Jing, W., and Raghavan, S. L. (2011). National science foundationsponsored colloquy on minority males in STEM. Journal of African American Males in Education, 2(1), $115-139$. 
Garriott, P. O., Flores, L.Y., and Martens, M. P. (2013). Predicting the math/science career goals of low-income prospective first-generation college students. Journal of Counseling Psychology, 60(2), 200-209.

Gasman, M., and Nguyen, T. H. (2014). Historically black colleges and universities (HBCUs): Leading our nation's effort to improve the science, technology, engineering, and mathematics (STEM) pipeline. Texas Education Review, 2(1), 75-89.

Gayles, J. G., and Ampaw, F. (2014). The impact of college experiences on degree completion in STEM fields at four-year institutions: Does gender matter? The Journal of Higher Education, 85(4), 439-468.

Habley, W. R., Bloom, J. L., Robbins, S., and Robbins, S. B. (2012). Increasing persistence: research-based strategies for college student success. San Francisco, CA: John Wiley \& Sons.

Habley, W., and McClanahan, R. (2010). What works in student retention? Fourth National Survey (ACT Policy Report). Washington, DC: ACT, Inc.

House, J. D. (1995). Noncognitive predictors of achievement in introductory college chemistry. Research in Higher Education, 36(4), 473-490.

Hu, S., McCormick, A. C., and Gonyea, R. M. (2012). Examining the relationship between student learning and persistence. Innovative Higher Education, 37(5), 387-395.

Jones, W. A. (2011). Examining the relationship between student body racial diversity and college/university retention and graduation rates (Doctoral dissertation). Retrieved from http://etd.library.vanderbilt.edu/available/etd-03262011-110541/unrestricted/Jones_Dissertation.pdf

Kuh, G. D. (2008). High-impact educational practices: What they are, who has access to them, and why they matter. Washington, DC: Association of American Colleges and Universities.

Lewis, S. E. (2014). Investigating the longitudinal impact of a successful reform in general chemistry on student enrollment and academic performance. Journal of Chemical Education, 91(12), 2037-2044.

Luke, J., and Robert, T. (2015). Black men in higher education. New York: Routledge.

Perez, T., Cromley, J.G., and Kaplan, A. (2014). The role of identity development, values, and costs in college STEM retention. Journal of Educational Psychology, 106(1), 315-329.

Pharos Resources, LLC. (2015). Pharos retention intelligence solutions. Retrieved from http://www.pharosresources.com/products/pharos-retention-intelligence-suite/pharos-360/

Reid, M. J., and Moore, J. L. (2008). College readiness and academic preparation for postsecondary education oral histories of first-generation urban college students. Urban Education, 43(2), 240-261.

Robb, C. A., Moody, B., and Abdel-Ghany, M. (2011). College student persistence to degree: The burden of debt. Journal of College Student Retention: Research, Theory and Practice, 13(4), 431-456.

Schreiner, L. A., Noel, P., and Cantwell, L. (2011). The impact of faculty and staff on high-risk college student persistence. Journal of College Student Development, 52(3), 321-338.

Stange, K. (2015). Differential pricing in undergraduate education: effects on degree production by field. Journal of Policy Analysis and Management, 34(1), 107-135.

Stassen, M. L. (2003). Student outcomes: The impact of varying living-learning community models. Research in Higher Education, 44(5), 581-613.

STEM undergraduates. International Innovations. 86-88. Retrieved from http://www.wesley.edu/fileadmin/editors_images/Academics/Biology/p86-88_Malcom_DSouza.pdf

Szelényi, K., Denson, N., and Inkelas, K. K. (2013). Women in STEM majors and professional outcome expectations: The role of living-learning programs and other college environments. Research in Higher Education, 1-23.

Tai, R. H., Sadler, P. M., \& Mintzes, J. J. (2006). Factors influencing college science success. Journal of College Science Teaching, 36(1), 52-60.

Tinto, V. (2012). Completing college: Rethinking institutional action. Chicago: University of Chicago Press.

University of Delaware NSF EPSCoR. (2010). Delaware experimental program to stimulate competitive research. Retrieved from www.epscor.udel.edu

Wesley College. (2011). Wesley college cannon scholar program. Retrieved from http://www.wesley.edu/academics/programs/undergraduate-programs/cannon-scholars.html

Wesley College. (2011). Wesley college core-curriculum. Retrieved from $\mathrm{http} / / / \mathrm{www} . w e s l e y . e d u / a c a d e m i c s /$ programs/core-curriculum.html

Wesley College. (2011). Delaware EPSCoR RII. Retrieved from http://www.wesley.edu/academics/grants/delawareepscor.html

Wesley College. (2011). INBRE. Retrieved from http://www.wesley.edu/academics/grants/inbre.html. 
Wesley College. (2011). Institutional research. Retrieved from http://www.wesley.edu/academics/accreditationassessment/institutional-research.html

Wesley College. (2011) Scholars day. Retrieved from http://www.wesley.edu/academics/scholars-day.html Wesley College. (2011). Retrieved from www.wesley.edu.

Xu, Y. J. (2013). Career outcomes of STEM and non-STEM college graduates: Persistence in majored-field and influential factors in career choices. Research in Higher Education, 54(3), 349-382 
NOTES 